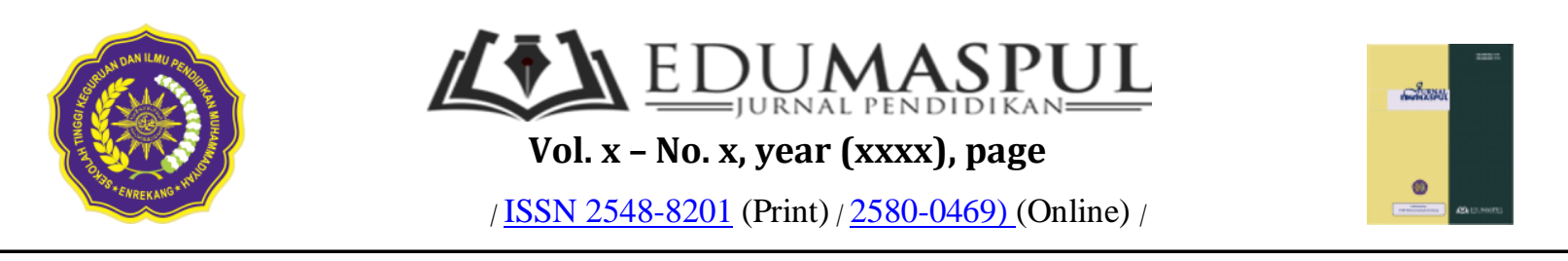

\title{
Manajemen PAUD Berdaya Saing Untuk Meningkatkan Mutu Pendidikan
}

\author{
Desi Siti Aisah ${ }^{1}$, Ulfah², Wika Karina Damayanti ${ }^{3}$, Ujang Cepi Barlian ${ }^{4}$ \\ ${ }^{1}$ (IImu Pendidikan, Universitas Islam Nusantara Bandung, Indonesia). \\ 2 (IImu Pendidikan, Universitas Islam Nusantara Bandung, Indonesia). \\ 3 (IImu Pendidikan, Universitas Islam Nusantara Bandung, Indonesia). \\ ${ }^{4}$ (IImu Pendidikan, Universitas Islam Nusantara Bandung, Indonesia). \\ * Corresponding Author. E-mail: ㅁaisyahnoer238@yahoo.com
}

\begin{tabular}{|l|l|l|}
\hline Receive: $d d /$ month/year & Accepted: & Published:
\end{tabular}

\begin{abstract}
Abstrak
Tujuan penelitian ini adalah untuk memperoleh gambaran tentang manajemen PAUD berdaya saing untuk meningkatkan mutu pendidikan. Penelitian ini menggunakan metode penelitian kepustakaan atau library research, yakni penelitian yang dilakukan melalui mengumpulkan data atau karya tulis ilmiah yang bertujuan dengan obyek penelitian atau pengumpulan data yang bersifat kepustakaan, atau telaah yang dilaksanakan untuk memecahkan suatu masalah yang pada dasarnya tertumpu pada penelaahan kritis dan mendalam terhadap bahan-bahan pustaka yang relevan. Hasil penelitian ini menujukkan bahwa Perencanaan dalam manajemen PAUD berdaya saing diimplementasikan dalam merumuskan visi, misi, tujuan, program-program kegiatan melalui program tahunan dan program semesteran, serta menempatkan Sumber Daya Manusia (SDM) yang berbeda sesuai dengan kompetensinya. Pelaksanaan PAUD berdaya saing diawali dengan melakukan analisis SWOT untuk menentukan kelemahan dan kelebihan lembaga. Pelaksanaan program dan kegiatan harus disesuaikan dengan kondisi yang ada dan dokumen perencanaanya, seperti RPP. Evaluasi ketercapaian indikator keberhasilan program kegiatan PAUD menjadikan anak usia dini menjadi pribadi yang sesuai dengan profil lulusan lembaga PAUD. Hal itu pun dapat diperoleh manakala dilakukan evaluasi terhadap program kegiatan PAUD pada lembaga PAUD tersebut. Pembenahan pengelolaan PAUD di daerah perlu ditingkatkan lagi agar mampu memberikan pelayanan prima bagi mayarakat, khususnya bagi anak-anak usia dini. Manajemen berdaya saing mampu diimplementasikan dalam pengelolaan PAUD sehari-hari.
\end{abstract}

Kata Kunci: Manajemen, PAUD

\begin{abstract}
The purpose of this study is to obtain an overview of competitive PAUD management to improve the quality of education. This research uses the library research method or library research, which is research conducted through collecting data or scientific papers aimed at the object of research or collection of data in the form of literature, or a study carried out to solve a problem which is basically based on critical and in-depth study. against relevant library materials. The results of this study indicate that planning in PAUD management is
\end{abstract}


competitively implemented in formulating the vision, mission, objectives, activity programs through annual and semester programs, as well as placing different Human Resources (HR) according to their competence. The implementation of competitive PAUD begins with conducting a SWOT analysis to determine the weaknesses and strengths of the institution. The implementation of programs and activities must be adapted to existing conditions and planning documents, such as RPP. Evaluation of the achievement of indicators for the success of the PAUD activity program makes early childhood into a person that fits the profile of the PAUD graduate institution. This can also be obtained when an evaluation of the PAUD program is carried out at the PAUD institution. The management of PAUD in the regions needs to be improved again so that it is able to provide excellent service to the community, especially for children of early age. Competitive management can be implemented in day-today PAUD management.

Keywords: Management, PAUD

\section{Pendahuluan}

Pendidikan merupakan hak setiap warga negara, tidak terkecuali pendidikan di usia dini yang merupakan hak warga negara dalam mengembangkan potensinya sejak dini. Anak usia dini merupakan pondasi terbaik dalam mengembangkan kehidupan seseorang di masa depan. Pendidikan yang diberikan dalam usia dini dapat mengoptimalkan kemampuan dasar anak dalam menerima proses pendidikan di usia berikutnya. Pendidikan merupakan upaya yang terorganisir, berencana dan berlangsung kontinu (terus menerus sepanjang hayat) ke arah membina manusia/anak didik menjadi insan paripurna, dewasa dan berbudaya (civilized) (Sauri, 2016).

Pada hakikatnya belajar harus berlangsung sepanjang hayat. Untuk menciptakan generasi yang berkualitas, pendidikan harus dilakukan sejak usia dini dalam hal ini melalui Pendidikan Anak Usia Dini (PAUD), yaitu pendidikan yang ditujukan bagi anak sejak lahir hingga usia 6 tahun. PAUD menjadi sangat penting mengingat potensi kecerdasan dan dasardasar perilaku seseorang terbentuk pada rentang usia ini. Sedemikian pentingnya masa ini sehingga usia dini sering disebut the golden age (usia emas). (Juhji, 2020)
Peraturan mengenai pendidikan anak usia dini tertuang dalam Undang-undang No. 20 Tahun 2003 tentang Sistem Pendidikan Nasional, dimana keberadaan pendidikan usia dini diakui secara sah. Hal ini diatur dalam Pasal 28, di mana pendidikan anak usia dini diarahkan pada pendidikan pra-sekolah yaitu anak usia 0-6 tahun. Pendidikan Anak Usia Dini (PAUD) adalah suatu upaya pembinaan yang ditujukan bagi anak sejak lahir sampai dengan usia enam tahun yang dilakukan melalui pemberian rangsangan pendidikan untuk membantu pertumbuhan dan perkembangan jasmani dan rohani agar anak memiliki kesiapan dalam memasuki pendidikan lebih lanjut. PAUD dapat berlangsung secara formal melalui Taman Kanak-Kanak (TK) untuk anak usia 4-6 tahun atau secara informal melalui PAUD (informal) atau kelompok bermain untuk anak usia 0-6 tahun. Dengan diberlakukannya Undang-Undang Nomor 20 Tahun 2003 tentang Sistem Pendidikan Nasional, maka sistem pendidikan di Indonesia terdiri dari pendidikan anak usia dini, pendidikan dasar, pendidikan menengah, dan pendidikan tinggi yang keseluruhannya merupakan kesatuan yang sistemik.

Titik Berat PAUD adalah terwujudnya pertumbuhan dan perkembangan fisik 
(koordinasi motorik halus dan kasar), kecerdasan (daya pikir, daya cipta, kecerdasan emosi, kecerdasan spiritual), sosio emosional (sikap dan perilaku serta agama) bahasa dan komunikasi, sesuai dengan keunikan dan tahap-tahap perkembangan yang dilalui oleh anak usia dini. Tujuan utama PAUD adalah untuk membentuk anak yang berkualitas, yaitu anak yang tumbuh dan berkembang sesuai dengan tingkat perkembangannya sehingga memiliki kesiapan yang optimal di dalam memasuki pendidikan dasar serta mengarungi kehidupan di masa dewasa. Tujuan penyertanya adalah untuk membantu menyiapkan anak mencapai kesiapan belajar (akademik) di sekolah. Untuk mencapai tujuan tersebut maka pembelajaran pada anak usia dini sangatlah penting. Dalam upaya peningkatan pembelajaran dalam jenjang PAUD, diperlukan adanya sebuah kerangka dasar kurikulum dan standar kompetensi anak usia dini yang berlaku secara nasional. Kerangka dasar kurikulum dan standar kompetensi adalah rambu-rambu yang dijadikan acuan dalam penyusunan kurikulum dan silabus (rencana pembelajaran) pada tingkat satuan pendidikan. Oleh karena itu Pengelolaan pendidikan yang baik akan dapat menciptakan sumber daya manusia (SDM) yang berkualitas.

Manajemen PAUD berdaya saing diartikan sebagai kegiatan sistemik dan sistematis yang dilakukan oleh kepala PAUD untuk meningkatkan kinerja pendidik PAUD dalam menyelenggarakan layanan PAUD melalui berbagai program kegiatan PAUD unggulan yang sesuai dengan standar PAUD dan sesuai dengan kebutuhan masyarakat agar tumbuhkembang anak berlangsung optimal dan memiliki kesiapan untuk belajar di jenjang berikutnya (Wiyani, 2017).

Meskipun penyelenggaraan PAUD telah menjamur, namun dalam segi pengelolaannya masih banyak kelemahan. Problematika pengelolaan program pendidikan anak usia dini meliputi hal yang menyangkut penyelenggaraan program, proses pembelajaran, dan evaluasi. Program pendidikan anak usia dini pada masa sekarang ini sangat dibutuhkan masyarakat dalam menjawab tantangan pendidikan anak usia dini. Masih terdapat berbagai masalah dalam pengembangan program PAUD ini. Layanan PAUD yang bermutu dapat direalisasikan melalui pengelolaan penyelenggaraan PAUD yang optimal. Namun, saat ini masih banyak ditemukan lembaga PAUD yang mengalami kesulitan dalam menyelenggarakan PAUD yang optimal. Penyebabnya adalah karena keterbatasan kompetensi manajerial yang dimiliki oleh pengelola PAUD (Risaldy, 2014).

Anggaran yang digulirkan untuk pengembangan PAUD masih sedikit dan tidak sebanding dengan jumlah lembaga PAUD yang ada, selain itu kecilnya pendapatan lembaga PAUD yang diperoleh dari iuran siswa tidak cukup untuk memenuhi kebutuhan operasional dan kesejahteraan guru. Permasalahan ketiga adalah belum semua daerah memiliki SDM yang mumpuni untuk pembinaan PAUD hingga ketingkat operasional. Pemerintah telah menyediakan dana khusus bagi pendidikan yaitu $20 \%$ dari dana APBN. Terbukti dalam Undang-undang 1945 pasal 31 ayat 4 yang berbunyi: "Negara memprioritaskan anggaran pendidikan sekurang-kurangnya dua puluh persen dari anggaran pendapatan dan belanja negara serta dari anggaran pendapatan dan belanja daerah untuk memenuhi kebutuhan penyelenggaraan pendidikan Nasional."

Walaupun telah disediakannya dana tersebut, namun pada kenyataannya masih banyak masyarakat di daerah pedesaan yang belum mendapatkan pendidikan layak sebagaimana mestinya. Bahkan 
pemerintah telah membuat program wajib belajar 9 tahun untuk meminimalisir rendahnya pendidikan di negara Indonesia ini, namun masih banyak yang belum mendapatkan pendidikan yang layak seperti yang di programkan pemerintah saat ini.

Satu upaya yang dilakukan adalah dengan menetapkan standar PAUD secara nasional sebagaimana yang diatur dalam Peraturan Menteri Pendidikan dan Kebudayaan (Permendikbud) Nomor 137 Tahun 2014 tentang Standar Nasional PAUD (Mulyasa, 2017),

Masih kurangnya tenaga kependidikan PAUD yang memenuhi standar kompetensi guru. Masih banyak guru PAUD yang berasal dari Kader Desa dan Pengurus RW yang tidak memenuhi kualifikasi pendidikan sebagai seorang guru (Nadeak, 2020). Hal ini sejalan dengan pendapat bahwa setiap individu dituntut untuk memiliki pengetahuan yang memadai agar mampu mengikuti dan menyesuaikan diri terhadap setiap perubahan yang sedang dan akan terjadi di masa yang akan datang (Barlian, 2016).

Sesuai peraturan Menteri Pendidikan Nasional Nomor 58 Tahun 2009 tentang Standar Pendidikan Anak Usia Dini Indonesia bab III tentang Standar Pendidik dan Tenaga Kependidikan dinyatakan bahwa pendidik anak usia dini adalah profesional yang bertugas merencanakan, melaksanakan proses pembelajaran, dan menilai hasil pembelajaran, serta melakukan pembimbingan, pengasuhan dan perlindungan anak didik. Untuk menjadi seorang guru pada PAUD tidak sembarangan, melainkan ada kualifikasi khusus agar nantinya hasil yang diperoleh dalam proses pembelajaran dapat maksimal dan menciptakan lulusan yang baik.

Dijelaskan dalan Undang-Undang No. 14 Tahun 2005 tentang Guru dan Dosen, bab IV bagian kesatu kualifikasi, kompetensi dan sertifikasi pasal 8 yaitu guru wajib memiliki kualifikasi akademik, kompetensi, sertifikasi pendidikan, sehat jasmani dan rohani, serta memiliki kemampuan untuk mewujudkan tujuan pendidikan nasional. Kemudian pada pasal 9 kualifikasi akademik sebagaimana yang dimaksud pada pasal 8 diperoleh melalui pendidikan tinggi program sarjana atau diploma empat (D4).

Permasalahan

implementasi

kurikulum yang tidak sesuai dengan perkembangan usia anak. Pembelajaran di PAUD dilakukan dengan bermain, namun banyak lembaga PAUD menerapkan pembelajaran baca tulis hitung untuk anak. Kerangka dasar kurikulum dan standar kompetensi adalah rambu-rambu yang dijadikan acuan dalam penyusunan kurikulum dan silabus pada tingkat satuan pendidikan. Pengelolaan pendidikan yang baik akan dapat menciptakan sumber daya manusia (SDM) yang berkualitas.

Pengembangan

kurikulum merupakan salah satu bagian penting dalam proses pendidikan. Kurikulum merupakan alat untuk membantu pendidik dalam melakukan tugasnya, sebab kurikulum secara umum dapat didefinisikan sebagai rencana yang dikembangkan untuk memperlancar proses pembelajaran. (Tanjung, 2019)

Kurikulum disusun agar memungkinkan pengembangan keragaman multi potensi, minat, kecerdasan bahasa, kognitif, sosial, emosional, spiritual, dan kinestetik/fisikmotorik, serta seni pada anak secara optimal sesuai dengan perkembangandan keunikan setiap anak. Pendidikan anak usia dini adalah masa yang penting, karena awal kehidupan anak merupakan masa yang paling tepat dalam memberikan dorongan atau upaya pengembangkan agar anak dapat berkembang secara optimal.

Semakin meningkatnya jumlah lembaga PAUD menunjukkan bahwa telah 
terjadi peningkatan terhadap penyelenggaraan layanan PAUD secara kuantitas di Indonesia. Idealnya, peningkatan kuantitas tersebut harus berbanding lurus dengan peningkatan kualitas lembaga PAUD. Namun dalam dataran riilnya, peningkatan kuantitas itu tidak dibarengi dengan peningkatan kualitas. Semakin meningkatnya jumlah lembaga PAUD juga akan menjadikan kompetisi antar lembaga PAUD di suatu daerah juga semakin meningkat. Suatu lembaga PAUD harus berkompetisi dengan lembaga PAUD lainnya untuk memperoleh kepercayaan masyarakat agar masyarakat mau menyekolahkan anaknya di lembaga PAUD tersebut. Ada semacam asumsi yang menyatakan bahwa suatu lembaga PAUD yang bisa memenangkan kompetisi dengan lembaga PAUD lainnya adalah lembaga PAUD yang sudah terakreditasi dan memiliki modal materi yang besar. Kemudian lembaga PAUD yang memiliki modal besar merupakan lembaga PAUD yang bonafid. Dengan modal yang besar tersebut, lembaga PAUD dapat mengadakan berbagai sarana dan prasarana pendidikan yang lengkap sesuai dengan standar sarana dan prasarana dalam standar PAUD.

Permasalahan diatas merupakan permasalahan yang banyak ditemui di lapangan. Permasalahan dalam rangka meningkatkan mutu layanan dapat dijadikan tolok ukur bagi kemajuan suatu lembaga yang menyelenggarakan PAUD. Dalam proses pengelolaan lembaga PAUD tidak terlepas dari manajemen penyelenggaraan yang baik. Manajemen pendidikan perlu dipergunakan sebagai landasan dasar untuk mengelola sebuah lembaga pendidikan. Manajemen menunjukan cara-cara yang lebih efektif dan efisien dalam pelaksanaan suatu pekerjaan. untuk menunjang semua hal tersebut, pengelolaan PAUD membutuhkan suatu perencanaan yang partisipatif, yakni dengan melibatkan semua pihak yang terlibat dalam kegiatan mulai dari perencanaan, pelaksanaan, evaluasi, sampai pemanfaatan program yang direncanakan.

Manajemen pengelolaan pendidikan merupakan suatu proses yang dinamis. Hal ini dimengerti karena pendidikan harus selalu disesuaikan dengan semangat zaman agar selalu sesuai dengan tuntutan zaman yang selalu mengalami perkembangan. Reformasi pendidikan merupakan respon baik secara proaktif maupun reaktif sekaligus suatu keniscayaan terhadap perkembangan tuntutan global sebagai suatu upaya untuk mengadaptasikan sistem pendidikan yang mampu mengembangkan sumber daya manusia untuk memenuhi tuntutan zaman yang sedang berkembang. Manajemen pendidikan sebagai pendekatan pengembangan sumber daya menusia kompettif, sarana pembaruan social yang berkeadilan, serta pembaruan dunia pendidikan yang kontekstual, sangat penting bagi eksistensi lembaga pendidikan.

Mengelola pendidikan berdaya saing tidaklah mudah. Daya saing sekolah merupakan kemampuan sekolah untuk melakukan aktivitas-aktivitas pendidikan dengan cara sebaik atau bahkan lebih baik daripada sekolah-sekolah lain yang menawarkan jasa yang sama. Untuk itu dibutuhkan formula yang tepat dalam mengatur segala permasalahan manajemen Pendidikan Anak Usia Dini yang berdaya saing. Intervensi pendidikan meningkatkan perkembangan anak. Usaha untuk mengoptimalkan pertumbuhan dan perkembangan anak sebagai pribadi yang utuh, dilakukan melalui upaya pemeliharaan kesehatan, pemberian nutrisi, stimulasi kecerdasan, penyediaan kesempatan yang luas bagi anak untuk bereksplorasi dan belajar secara menyenangkan, pengasuhan dan 
bimbingan anak untuk memahami potensi dirinya dan berperan aktif dalam keluarga serta masyarakat.

Permasalahan dalam manajemen penyelenggaraan program PAUD yang meliputi empat tahapan yaitu tahap perencanaan, tahap pengorganisasian, tahap pelaksanaan, dan tahap pengawasan program. Permasalahan dalam perencanaan adalah kegiatan menyusun program tahunan sekolah. Proses pembelajaran meliputi permasalahan dalam pengembangan kurikulum PAUD, pengembangan metode dan pengembangan media pembelajaran PAUD. permasalahan evaluasi program PAUD meliputi evaluasi kinerja pendidik dan pengelola, evaluasi proses pembelajaran dan evaluasi dalam hasil belajar warga belajarnya.

Pembenahan

manajemen

pengelolaan PAUD memiliki tujuan untuk meningkatkan mutu dari layanan pendidikan tersebut. Dalam lingkungan sistem pendidikan, khususnya sekolah, penjaminan mutu merupakan tuntutan yang harus difokuskan oleh pihak sekolah demi kemajuan bersama. Hal ini didasarkan pada penyelenggaraan pendidikan yang bermutu merupakan hal yang menjadi sorotan utama oleh orang tua bahkan sampai ke tingkat satuan pendidikan. Setiap komponen pemangku kepentingan pendidikan, baik orang tua, masyarakat, dunia kerja, pemerintah dalam peranan dan kepentingannya masing-masing memeiliki kepentingan terhadap penyelenggaraan pendidikan yang bermutu. Mutu disebut pula sebagai definisi kualitas. Kualitas ini dicapai bilamana produk atau jasa memenuhi spesifikasi yang telah ditetapkan sebelumnya. Sama halnya dengan mutu pendidikan. Standar mutu pendidikan telah ditetapkan dalam delapan standar pendidikan yang tertuang dalam Peraturan Pemerintah Nomor 19 Tahun 2005 tentang
Standar Nasional Pendidikan. 8 standar pendidikan meliputi : standar Isi, standar proses, standar kompetensi lulusan, standar pendidik dan tenaga kependidikan, standar sarana dan prasarana, standar pengelolaan, standar pembiayaan, dan standar penilaian pendidikan.

Dengan manajemen paud yang telah dilaksanakan namun belum mampu meningkatkan mutu pendidikan anak usia dini. Atas dasar permasalahan tersebut maka perlu dilakukan penelitian lebih lanjut terkait "Manajemen PAUD berdaya saing untuk Meningkatkan Mutu Pendidikan".

\section{Metode}

Metode penelitian ini menggunakan metode kepustakaan. Adapun jenis penelitian yang digunakan dalam penelitian ini adalah penelitian kepustakaan atau library research, yakni penelitian yang dilakukan melalui mengumpulkan data atau karya tulis ilmiah yang bertujuan dengan obyek penelitian atau pengumpulan data yang bersifat kepustakaan, atau telaah yang dilaksanakan untuk memecahkan suatu masalah yang pada dasarnya tertumpu pada penelaahan kritis dan mendalam terhadap bahan-bahan pustaka yang relevan. (Sugiyono, 2015)

Sebelum melakukan telaah bahan pustaka, peneliti harus mengetahui terlebih dahulu secara pasti tentang dari sumber mana informasi ilmiah itu akan diperoleh. Adapun beberapa sumber yang digunakan antara lain; bukubuku teks, jurnal ilmiah,refrensi statistik, hasil-hasil penelitian dalam bentuk skripsi, tesis, desertasi,dan internet, serta sumbersumber lainnya yang relevan. (Sanusi, 2016)

Adapun metode pengumpuluan data penelitian ini diambil dari sumber data, Yang dimaksud sumber data dalam penelitian adalah subjek dari mana data 
dapat diperoleh. Apabila peneliti menggunakan dokumentasi, maka dokumen atau catatanlah yang menjadi sumber data, sedangkan isi catatan subjek penelitian atau variable penelitian. (Arikuntoro, 2006)

\section{Hasil dan Pembahasan}

\section{Perencanaan Paud Berdaya Saing}

Manajemen merupakan kegiatan pengelolaan yang dilakukan oleh seluruh anggota atau personel organisasi untuk mencapai tujuan organisasi yang telah disepakati bersama. Kesepakatan tersebut dibuat oleh para personel organisasi dan para pelanggan pengguna jasa maupun produk organisasi.

Sedangkan PAUD berdaya saing adalah kemampuan suatu lembaga PAUD dalam berlomba mendapatkan suatu hal dengan lembaga PAUD lainnya melalui penyelenggaraan Lembaga PAUD yang khas. Kekhasan tersebut bukan hanya menjadi pembeda antara satu Lembaga PAUD dengan Lembaga PAUD lainya tetapi juga menjadi modal untuk memenangkan persaingan dengan Lembaga paud lainya.

Perencanaan dalam manajemen PAUD berdaya saing diimplementasikan dalam: a) Merumuskan visi, misi, dan tujuan yang berbeda, b) Merumuskan program-program kegiatan PAUD yang berbeda, melalui program tahunan, atau program semesteran, dan c) Menempatkan Sumber Daya Manusia (SDM) yang berbeda sesuai dengan kompetensinya.

Dengan demikian, manajemen PAUD berdaya saing merupakan upaya mengelola suatu lembaga PAUD dengan menyelenggarakan layanan PAUD yang berbeda dengan lembaga PAUD lainnya untuk memenangkan persaingan dalam mendapatkan sesuatu yang berhubungan dengan lembaga PAUD. Misalnya persaingan untuk mendapatkan siswa baru, persaingan untuk mendapatkan prestasi akademik dan non akademik, serta persaingan untuk melengkapi sarana dan prasarana pendidikan.

Tujuan dari dilaksanakannya kegiatan manajemen PAUD berdaya saing adalah untuk menghasilkan berbagai program kegiatan PAUD unggulan yang dimiliki oleh suatu lembaga PAUD dan tidak dimiliki oleh lembaga PAUD lainnya. Program kegiatan PAUD unggulan itulah yang akan menjadi nilai jual suatu lembaga PAUD. Dengan nilai jual tersebut lembaga PAUD dapat menjadi lembaga PAUD yang berdaya saing selain itu juga untuk memenangkan persaingan dalam penyelenggaraan layanan PAUD dengan cara yang bermartabat. Bersaing dengan cara yang bermartabat dilakukan dengan mempertimbangkan dimensi etika dan moralitas serta profesionalisme guru PAUD.

\section{Pelaksanaan Manajemen PAUD Berdaya Saing}

Pelaksanaan langkah-langkah yang dilakukan oleh suatu lembaga PAUD dalam kegiatan manajemen PAUD berdaya saing antara lain:

1. Menganalisis hal-hal yang dipersaingkan antar lembaga PAUD

Pada langkah ini lembaga PAUD melakukan kajian terhadap keberlangsungan persaingan antar lembaga PAUD serta melakukan identifikasi terhadap hal-hal yang dipersaingkan antar lembaga PAUD. Hasil kajian dan identifikasi tersebut dijadikan sebagai bahan untuk menentukan apa sebenarnya yang paling banyak dipersaingkan antar lembaga PAUD. Sesuatu yang paling banyak dipersaingkan antar lembaga PAUD merupakan sesuatu yang dapat memberikan pengaruh terhadap eksistensi lembaga PAUD di masa kini dan di masa mendatang. Sebagian besar lembaga PAUD berstatus swasta. Eksistensi mereka sangat dipengaruhi 
oleh kepemilikan anak didiknya. Hal itu menjadikan rekruitmen anak didik baru menjadi sesuatu yang paling banyak dipersaingkan antar lembaga PAUD.

Ada beberapa prinsip yang harus di pegang dan diaktualisasikan oleh Lembaga PAUD agar bisa menjadi Lembaga PAUD yang bisa berkompetensi. Pertama menjadikan kompetensi sebagai sarana untuk berlomba dalam berbuat baik melalui praktik penyelenggaraan PAUD yang baik yang didasari oleh keimanan, kejujuran, kebenaran, dan keadilan yang dapat menjadikan masyarakat memiliki kepercayaan terhadap Lembaga PAUD. Kepercayaan tersebut merupakan hal yang mahal ataupun model yang paling berharga. Kedua, meyakini bahwa competitor utama Lembaga PAUD pada hakikatnya bukanlah Lembaga PAUD lain tetapi dirinya sendiri. Pimpinan, guru, serta karyawan Lembaga PAUD harus dapat mengalahkan kemalasan, ketakutan, keidak percayaan pada diri sendiri dan perasan rendah diri yang ada pada diri mereka. Hal itu bisa dilakukan manakala stakeholder PAUD senantiasa belajar untuk mengupgrade kemampuan atau kompetisinya serta berfikiran positif. Ketiga, penyelenggaraan layanan PAUD tidaklah berorientasi pada pencapaian profit tetapi pada pencapaiam ridho Allah SWT. Keempat, meyakini bahwa modal yang paling berharga dalam pengembangan PAUD bukanlah materi (tangible) tetapi ide-ide (intangible). Khususnya ide-ide tentang strategi pengembangan Lembaga PAUD berdaya saing. Jalanya strategi pengembanga tersebut dilandasi dengan keimanan, keikhlasan, kejujuran, kebenaan. Kepedulian, dan kepercayaan diri.

2. Melakukan analisis SWOT
Pada kegiatan analisis SWOT dilakukan analisis internal dan analisis eksternal lembaga PAUD. Analisis internal dilakukan untuk mendapatkan deskripsi tentang kekuatan-kekuatan dan kelemahan-kelemahan yang dimiliki oleh lembaga PAUD. Analisis eksternal dilakukan untuk mendapatkan gambaran tentang peluang dimiliki dan tantangan yang dihadapi oleh lembaga PAUD. Kekuatan-kekuatan yang dimiliki digunakan untuk mengatasi kelemahankelemahan, untuk memanfaatkan peluang dan untuk menghadapi tantangan. Peluang yang dapat dimanfaatkan dengan kelebihankelebihan yang dimiliki dapat menjadikan lembaga PAUD memiliki kemampuan mengatasi kelemahankelemahan dan dalam melakukan langkah antisipatif terhadap tantangan. Dengan demikan kekuatan-kekuatan dan peluangpeluang yang dimiliki oleh lembaga PAUD dapat dijadikan sebagai modal untuk memenangkan persaingan.

1) Strength atau kekuatan, adalah situasi atau kondisi sumber daya alam dan sumber daya manusia yang merupakan kekuatan dari lembaga. Strength ini bersifat internal. Contoh : Guru banyak (kuantitatif) dan berpengalaman (kualitatif), Sarpras lengkap dan Lembaga unggulan

2) Weaknesses atau kelemahan, adalah kelemahan yang terdapat di lembaga. Weaknesses ini juga bersifat internal. Contoh : Iklim di sekolah yang tidak kondusif, Kepemimpinan yang kurang baik, SDM kurang berkompeten dan Komunikasi yang kurang efektif antara pengelola dan pendidik/karyawan.

3) Opportunities atau peluang, Adalah peluang-peluang dari luar lembaga yang dapat dimanfaatkan untuk 
pengembangan lembaga. Contoh : Peluang kerjasama dengan lembaga profesional psikologi, Peluang menjadi lembaga percontohan, dan Peluang menjadi PAUD inklusi.

4) Threats atau ancaman, adalah kondisi yang mengancam dari luar yang ketika tidak, diantisipasi akan membahayakan keberlangsungan lembaga. Contoh: Anak usia dini dari lingkungan sekitar yang jumlahnya semakin sedikit, dan banyaknya lembaga PAUD yang lebih baik dan berkualitas berdiri di sekitar lembaga kita.

3. Memetakan keinginan dan kebutuhan wali murid

Setiap orangtua memiliki keinginan-keinginan terkait dengan tumbuh kembang anaknya dan mengharapkan lembaga PAUD mampu mewujudkan keinginan-keinginan itu dengan diselenggarakannya layanan PAUD yang prima. Para orangtua juga memiliki kebutuhan-kebutuhan terkait dengan tumbuh-kembang anaknya dan menghendaki agar lembaga PAUD mampu memenuhi kebutuankebutuhan tersebut dengan berbagai upaya atau usaha.

Hasil penelitian menunjukkan terdapat dua keinginan dari wali murid, yaitu: (1) wali murid menginginkan agar anak-anaknya bisa mendapatkan layanan PAUD secara maksimal agar tumbuh-kembang anak bisa berlangsung optimal; (2) wali murid ingin agar anak merasa nyaman dalam kegiatan belajar. Kenyamanan belajar tersebut menjadikan anak memiliki motivasi belajar yang tinggi. Harapannya dengan motivasi belajar yang tinggi kemudian anak bisa mencapai hasil belajar yang maksimal. Lembaga PAUD harus berusaha memenuhi keinginan wali murid karena memang eksistensi PAUD akan sangat dipengaruhi oleh kemampuan pihak PAUD dalam memenuhi keinginan wali murid. Dengan kata lain, maju atau mundurnya PAUD akan sangat dipengaruhi oleh kemampuan PAUD dalam melayani wali murid sesuai dengan keinginan (Maryani, 2019).

Kemudian cara yang digunakan untuk mengidentifikasi kebutuhan wali murid adalah dengan menyediakan kotak saran, memberi kebebasan mengutarakan apa yang dibutuhkan saat pertemuan wali murid ataupun saat berkomunikasi secara nonformal baik di lingkungan PAUD maupun di grup jejaring sosial. Hal yang dibutuhkan oleh wali murid dari layanan PAUD yang diselenggarakan yaitu informasi tentang kegiatan anak serta informasi tentang hasil belajar anak dan masalah-masalah yang dihadapi oleh anak ketika belajar. Wali murid membutuhkan hal itu untuk mempersiapkan waktu dan biaya serta strategi dalam menyiapkan kebutuhan fisik serta kebutuhan psikis anak. Sementara itu identifikasi keluhan dilakukan dengan menyediakan kotak saran dan memberi keluasan menceritakan keluhan melalui WhatsApp. Hal-hal yang dikeluhkan oleh wali murid yaitu tentang masalah administrasi yang terkadang merepotkan, pelayanan guru yang kurang sesuai dengan harapan, kenakalan anak, serta keterbatasan sarana dan prasarana. Wali murid merasa kurang nyaman dengan masalahmasalah dan keadaan-keadaan tersebut.

4. Merancang dan melaksanakan program kegiatan PAUD

Program-program kegiatan PAUD dirancang untuk mencapai profil lulusan dan tujuan dalam penyelenggaraan layanan PAUD. Ketika profil lulusan dan tujuan tersebut tercapai maka visi 
lembaga PAUD dapat tercapai. Ketercapaian visi akan menjadikan keinginan dan kebutuhan orangtua terpenuhi. Merancang suasana pembelajaran yakni dengan cara :

a) Ruangan dan halaman di atur guna menumbuhkan atau membangkitkan minat bereksplorasi anak dengan cara meletakkan media pembelajaran secara menarik. Pengaturan ruangan dan halaman dapat disesuaikan dengan tema mingguan.

b) Metode pembelajaran yang dipilih hendaknya merangsang anak untuk bereksplorasi (penjajakan), menemukan, dan memanfaatkan benda-benda di sekitarnya

5. Menjalankan atau melaksanakan program PAUD dan pembelajaran

Setelah berbagai program kegiatan PAUD disusun, langkah selanjutnya dalam implementasi manajemen PAUD berdaya saing adalah menetapkan pelaksana program kegiatan PAUD. Tujuan dari penetapan pelaksana program kegiatan PAUD adalah untuk menentukan siapa pihak yang menjadi penanggungjawab dalam pelaksanaan suatu program kegiatan PAUD. Berikut adalah syarat dalam pembelajaran PAUD :

a) Proses pembelajaran tidak perlu diatur dalam tata urutan yang ketat. Anak hendaknya di beri kesempatan untuk memilih acara kegiatan pembelajarannya

b) Dalam melaksanakan kegiatan pembelajarannya, sebaiknya di mulai dengan kegiatan yang dapat merangasang minat anak

c) Kegiatan yang dijalankan anak dalam satu hari hendaknya bervariasai antara kegiatan yang bersifat ramai dan kegiatan yang melatih konsentrasi anak.
6. Menyusun SOP Program Kegiatan PAUD Standard Operating Procedure (SOP) digunakan untuk memberi keseragaman tindakan operasional yang dilakukan oleh setiap anggota pada suatu organisasi. Setiap program kegiatan PAUD pada suatu lembaga PAUD juga harus memiliki SOP. Itulah sebab harus disusun SOP program kegiatan PAUD. Tujuan dari penyusunan SOP adalah untuk mendapatkan deskripsi tentang langkah-langkah yang harus dilakukan oleh setiap pihak yang terlibat dalam melaksanakan suatu program kegiatan PAUD. SOP program kegiatan PAUD disusun melalui rapat kerja yang diikuti oleh kepala PAUD, pendidik PAUD, tenaga kependidikan PAUD, dan perwakilan wali murid. Langkah-langkah yang dilakukan dalam menyusun SOP program kegiatan PAUD adalah sebagai berikut:

a) Menentukan waktu dan tempat pelaksaan SOP program kegiatan PAUD.

b) Menentukan personil yang terlibat dalam pelaksanaan SOP program kegiatan PAUD.

c) Menyusun alur pelaksanaan suatu program kegiatan PAUD untuk mencapai suatu indikator keberhasilan program kegiatan PAUD.

d) Penyusunan alur pelaksanaan suatu program kegiatan PAUD harus memilik relevansi dengan strategi pencapaian indikator keberhasilan program kegiatan PAUD.

e) Melakukan pengkajian terhadap alur pelaksanaan suatu program kegiatan PAUD. Alur pelaksanaan tersebutlah yang kemudian akan dijadikan sebagai SOP.

f) Melakukan uji coba terhadap SOP program kegiatan PAUD hasil kajian. 
g) Melakukan revisi terhadap SOP program kegiatan PAUD yang telah diuji cobakan

h) Menetapkan SOP program kegiatan PAUD yang telah direvisi.

i) Mensosialisasikan SOP program kegiatan PAUD yang telah ditetapkan melalui berbagai media.

7. Melaksanakan Program Kegiatan PAUD sesuai dengan SOP

Program kegiatan PAUD dilaksanakan untuk mencapai indikator keberhasilan program kegiatan PAUD. Jika ke semua indikator tersebut terpenuhi maka akan dihasilkan anak usia dini yang memiliki profil lulusan lembaga PAUD yang telah ditetapkan. SOP program kegiatan PAUD menjadi semacam guideline yang digunakan dalam melaksanakan berbagai program kegiatan PAUD. Pada saat pelaksanaannya, tidak menutup kemungkinan ditemukan SOP program kegiatan PAUD yang kurang tepat untuk dijadikan sebagai guideline suatu kegiatan. SOP program kegiatan PAUD tersebut sudah barang tentu harus direvisi

\section{Evaluasi Manajemen PAUD Berdaya Saing}

Berbagai program kegiatan PAUD dilaksanakan untuk mencapai indikator keberhasilan program kegiatan PAUD. Ketercapaian indikator keberhasilan program kegiatan PAUD menjadikan anak usia dini menjadi pribadi yang sesuai dengan profil lulusan lembaga PAUD. Jika hal itu dapat terjadi, maka visi lembaga PAUD pun akan terwujud. Hal itu pun dapat diperoleh manakala dilakukan evaluasi terhadap program kegiatan PAUD pada lembaga PAUD tersebut. Jadi tujuan dilakukannya evaluasi program kegiatan PAUD adalah untuk menentukan tingkat pencapaian keberhasilan program kegiatan PAUD.

\begin{abstract}
Langkah-langkah yang dilakukan dalam evaluasi keberhasilan program kegiatan PAUD antara lain:
\end{abstract}

1. Menentukan jenis teknik evaluasi yang digunakan, apakah dengan teknik tes atau non tes. Teknik tes seperti tes tertulis dalam bentuk pilihan ganda, isian, essay, menjodohkan, dan lainnya. sedangkan teknik non tes seperti wawancara, observasi, eksperimen, dan lainnya. Jika melihat sisi psikologis anak usia dini, maka teknik non tes menjadi pilihan yang tepat untuk digunakan.

2. Menentukan dan menyusun instrumen yang akan digunakan berdasarkan teknik evaluasi yang telah ditentukan serta indikator keberhasilan program kegiatan PAUD.

3. Melakukan uji coba terhadap instrumen yang telah disusun dan meminta pendapat pakar untuk memvalidasi instrumen.

4. Melakukan revisi terhadap instrumen yang telah diuji cobakan.

5. Menetapkan instrumen yang telah direvisi dan mensosialisasikannya.

\section{Simpulan}

PAUD berdaya saing adalah kemampuan suatu lembaga PAUD dalam berlomba mendapatkan suatu hal dengan lembaga PAUD lainnya melalui penyelenggaraan layanan PAUD yang khas. Sedangkan manajemen PAUD berdaya saing adalah upaya mengelola suatu lembaga PAUD dengan menyelenggarakan layanan PAUD yang berbeda dengan lembaga PAUD. Perencanaan dalam manajemen PAUD berdaya saing diimplementasikan dalam merumuskan visi, misi, tujuan, program-program kegiatan melalui program tahunan dan program semesteran, serta menempatkan Sumber Daya Manusia (SDM) yang berbeda sesuai dengan kompetensinya. Pelaksanaan PAUD berdaya saing diawali dengan melakukan analisis SWOT untuk 
menentukan kelemahan dan kelebihan lembaga. Pelaksanaan program dan kegiatan harus disesuaikan dengan kondisi yang ada dan dokumen perencanaanya, seperti RPP. Evaluasi ketercapaian indikator keberhasilan program kegiatan PAUD menjadikan anak usia dini menjadi pribadi yang sesuai dengan profil lulusan lembaga PAUD. Hal itu pun dapat diperoleh manakala dilakukan evaluasi terhadap program kegiatan PAUD pada lembaga PAUD tersebut. Pembenahan pengelolaan PAUD di daerah perlu ditingkatkan lagi agar mampu memberikan pelayanan prima bagi mayarakat, khususnya bagi anak-anak usia dini. Manajemen berdaya saing mampu diimplementasikan dalam pengelolaan PAUD sehari-hari.

\section{Daftar Pustaka}

[1] Arikuntoro, S. (2006). Prosedur Penelitian Suatu Pendekatan Praktik. Jakarta : Rieneka Cipta.

[2] Barlian. (2016). Pengaruh Motivasi Dan Iklim Organisasi Terhadap Kinerja Pegawai Pada PT. Kesuma Jakarta. Jurnal Manajemen, Kepemimpinan Dan Supervisi Pendidikan., 1(2).

[3] Juhji. (2020). Manajemen Humas Sekolah. Bandung: Widina Bhakti Persada.

[4] Maryani. (2019). Implementasi Activity Based Costing $(A B C)$ di RA Masyithoh Mertasinga Cilacap. Cilacap: RA Masyithoh Mertasinga.

[5] Mulyasa. (2017). Strategi pembelajaran PAUD. Bandung : Rosda.

[6] Nadeak, B. (2020). Manajemen Humas Pada Lembaga Pendidikan. Bandung: Widina Bhakti Persada.

[7] Risaldy. (2014). Manajemen pengelolaan sekolah anak usia dini. Jakarta: Luxima.

[8] Sanusi, A. (2016). Metodologi Penelitian Bisnis. Jakarta : Salemba Empat.
[9] Sauri, S. (2016). Strategi Pembangunan Bidang Pendidikan Untuk Mewujudkan Pendidikan Bermutu. Bandung: UPI.

[10] Sugiyono. (2015). Metode Penelitian Pendidikan (Pendekatan Kuantitatif,. Kualitatif dan R\&D). Bandung: CV. Alfabeta.

[11] Tanjung, R. (2019). Manajemen Pelayanan Prima Dalam Meningkatkan Kepuasan Mahasiswa Terhadap Layanan Pembelajaran (Studi Kasus di STIT Rakeyan Santang Karawang). MEA (Manajemen, Ekonomi, \& Akuntansi), 3(1), 234-242.

[12] Wiyani. (2017). Manajemen PAUD Berdaya Saing. Yogyakarta: Gavamedia.

\section{Profil Penulis}

Desi Siti Aisah. Penulis lahir di Bandung pada tanggal 23 Desember 1979. Pendidikan tinggi penulis antara lain (a) Program D3 FMIPA Universitas Padjadjaran lulus tahun 2001 (b) program Strata 1 fakultas keguruan dan ilmu pendidikan Matematika Uninus Bandung lulus pada tahun 2010 (c) Program Strata II Magister manajemen IKOPIN lulus tahun 2018, Penulis merupakan Pengajar di Bimbingan Belajar kedinasan di Jatinangor dan saat ini merupakan mahasiswa program doktoral ilmu pendidikan, Universitas Islam Nusantara Bandung.

Ulfah. Penulis lahir di Tegal pada tanggal 14 Maret 1986. Pendidikan tinggi penulis antara lain (a) Program Strata I Psikologi Pendidikan dan Bimbingan Universitas Pendidikan Indonesia lulus pada tahun 2009; (b) Program Strata II Bimbingan dan Konseling pada Universitas Pendidikan Indonesia lulus pada tahun 2011; Penulis merupakan Dosen Bimbingan dan Konseling pada Program Studi Pendidikan Agama Islam, Fakultas Agama Uslam, Universitas Islam Nusantara 
Bandung dan saat ini merupakan mahasiswa program doktoral ilmu pendidikan, Universitas Islam Nusantara Bandung.

Wika Karina Damayanti. Penulis lahir di Bandung pada tanggal 8 Oktober 1988. Pendidikan tinggi penulis antara lain (a) Program Strata I Pendidikan Luar Sekolah Universitar Pendidikan Bandung lulus tahun 2010; (b) Program Strata I IImu Hukum Sekolah Tinggi Hukum Bandung lulus tahun 2012; (c) Program Strata II Pendidikan Luar Sekolah Sekolah Tinggi Keguruan dan Ilmu Pendidikan Siliwangi Bandung Lulus tahun 2014; Penulis merupakan Pegawai Negeri Sipil di Dinas Pendidikan Kabupaten Bandung Barat dan saat ini merupakan mahasiswa program doktoral ilmu pendidikan, Universitas Islam Nusantara Bandung.

Ujang Cepi Barlian. Penulis merupakan Dosen Pascasarjana Universitas Islam Nusantara Bandung. Pendidikan tinggi penulis antara lain (a) Program Strata I Universitas Pasundan Bandung lulus pada tahun 1995; (b) Program Strata II Universitas Garut lulus pada tahun 2003; (c) Program Strata III Universitas Pendidikan Indonesia lulus pada tahun 2011. 